\title{
Luteinizing hormone beta gene polymorphism and its effect on semen quality traits and luteinizing hormone concentrations in Murrah buffalo bulls
}

\author{
Jagish Kour Reen ${ }^{1}$, Ramesha Kerekoppa ${ }^{1, *}$, Revanasiddu Deginal', Maneesh Kumar Ahirwar', \\ Uday Kannegundla', Satish Chandra', Divya Palat', Dayal Nitai Das', Mukund Amritrao Kataktalware ${ }^{2}$, \\ Sakthivel Jeyakumar ${ }^{2}$, and Shri krishna Isloor ${ }^{3}$
}

\begin{abstract}
* Corresponding Author: Ramesha Kerekoppa Tel: +91-9916499636, Fax: +91-080-25710161,

E-mail: kpragb@gmail.com
\end{abstract}

${ }^{1}$ Genetics Laboratory, Dairy Production Section, ICAR National Dairy Research Institute, Southern Regional

Station, Adugodi, Bengaluru-560030, India

2 Livestock Research Centre, ICAR-National Dairy

Research Institute, Southern Regional Station,

Adugodi, Bengaluru-560030 India

${ }^{3}$ Department of Microbiology, Veterinary College,

Hebbal, Bengaluru 560024, India

ORCID

Jagish Kour Reen

https://orcid.org/0000-0002-2232-0246

Ramesha Kerekoppa

https://orcid.org/0000-0003-1828-2192

Revanasiddu Deginal

https://orcid.org/0000-0002-4333-5148

Maneesh Kumar Ahirwar

https://orcid.org/0000-0003-0630-880X

Uday Kannegundla

https://orcid.org/0000-0001-5819-7019

Satish Chandra

https://orcid.org/0000-0002-9508-3958

Divya Palat

https://orcid.org/0000-0003-2351-0241

Dayal Nitai Das

https://orcid.org/0000-0001-9194-7969

Mukund Amritrao Kataktalware

https://orcid.org/0000-0001-8802-5197

Sakthivel Jeyakumar

https://orcid.org/0000-0001-7698-4016

Shri krishna Isloor

https://orcid.org/0000-0002-3264-3874

Submitted Sept 10, 2017; Revised Oct 27, 2017; Accepted Nov 24, 2017
Objective: Present investigation was aimed to study the Single Nucleotide Variants of the luteinizing hormone beta $(L H \beta)$ gene and to analyze their association with the semen quality (fresh and post-thawed frozen semen) and luteinizing hormone (LH) concentrations in Murrah buffalo bulls.

Methods: Polymerase chain reaction-single stranded conformational polymorphism (PCRSSCP) and Sanger sequencing method is used to study genetic variability in $L H \beta$ gene. $\mathrm{LH}$ assay was carried out using enzyme-linked immunosorbent assay method. A fixed general linear model was used to analyze association of single nucleotide polymorphism (SNP) of $L H \beta$ gene with semen quality in 109 and LH concentrations in 80 Murrah bulls.

Results: $L H \beta$ gene was found to be polymorphic. Total six SNPs were identified in $L H \beta$ gene g C356090A, g C356113T, g A356701G, g G355869A, g G356330C, and g G356606T. Single Stranded Conformational Polymorphism variants of pattern 2 of exon $1+$ pattern 2 of exon $2+$ pattern 1 of exon 3 had highly significant $(\mathrm{p}<0.01)$ effect on sperm concentration (million/mL), percent mass motility, acrosome integrity and membrane integrity in fresh and frozen semen whereas significant $(p<0.05)$ effect was observed on percent live spermatozoa. SSCP variants of pattern 2 of exon 1+pattern 2 of exon 2+pattern 1 of exon 3 had highly significant $(\mathrm{p}<0.01)$ effect on luteinizing hormone concentrations too.

Conclusion: The observed association between SSCP variants of $L H \beta$ gene with semen quality parameters and $\mathrm{LH}$ concentrations indicated the possibilities of using $L H \beta$ as a candidate gene for identification of markers for semen quality traits and $\mathrm{LH}$ concentrations in Murrah buffaloes.

Keywords: Polymerase Chain Reaction-Single Stranded Conformational Polymorphism (PCR-SSCP); Murrah Bull; Luteinizing Hormone Beta $(L H \beta)$; LH Concentrations; Semen Quality Traits; Enzyme-linked Immunosorbent Assay (ELISA)

\section{INTRODUCTION}

Selection of high quality bulls is a prerequisite for the cost-effective frozen semen production and dissemination of superior germplasm. However, direct selection for semen quality traits is not possible because of their low heritability [1]. Therefore, marker assisted selection could be used for selection of superior males at an early age. With the development of molecular biological techniques, the candidate gene method might offer the specific markers to predict sperm quality traits in bulls. Researchers [2] indicated that hormone and hormone receptors are good candidate genes for bull sperm traits due to their modulating roles in many male reproductive pathways, thus they are considered to be good candidate genes for 
the reproductive traits.

Luteinizing hormone (LH) is a pituitary-derived heterodimeric glycoprotein, consisting of the common $\alpha$-subunit with human chorionic gonadotropin, follicle stimulating hormone and thyroid stimulating hormone and a unique $\beta$-subunit conferring the biological specificity of LH $[3,4]$. Luteinizing hormone beta polypeptide $(L H \beta)$ gene is a single copy gene [5], located on the long (q) arm of chromosome 18 and consists of 3 exons. Studies indicated that mutation in LH beta subunit, causes its inactivation leading to lack of leydig cells, absence of spontaneous puberty and infertility in human [6] and a genetic variant of the $L H \beta$ might affect susceptibility to prostate cancer via altered testosterone secretion [7]. The polymorphism study of $L H \beta$ gene has been done [8], however, a study regarding the use of this gene as candidate gene marker for sperm quality traits and hormone concentrations in Murrah bulls is yet to be conducted. Therefore, present investigation was undertaken to study the single nucleotide variants of the $L H \beta$ gene and to analyze their association with the semen quality (fresh and post-thawed frozen semen) and LH concentrations in Murrah bulls.

\section{MATERIALS AND METHODS}

\section{Animal care}

All the experimental procedures were conducted as per the guidelines of the Institutes Animal Ethics Committee (IAEC) of ICAR-NDRI, Bengaluru, India.

\section{Experimental animals}

The present investigation was carried out in Murrah bulls maintained at State Livestock Breeding and Training Center (SLBTC) Hessarghatta, Bengaluru, Nandini Sperm Station (NSS), Hessarghatta, Bengaluru, and Centralized Semen Collection Centre of Livestock Breeding and Training Centre (LBTC), Dharwad. Bulls were maintained under standard management conditions adhering to Minimum Standard Protocols as recommended by the Department of Dairying, Animal Husbandry \& Fisheries, Government of India.

\section{Blood collection and isolation of DNA}

About ten milliliters of blood was collected aseptically from jugular vein of each animal $(n=109)$ in a vacutainer tube containing $0.5 \%$ ethylenediaminetetraacetic acid (EDTA). After collection, the samples were stored at $4^{\circ} \mathrm{C}$ and DNA was isolated within 24 hours of collection by high salt method [9]. The working solution of DNA was prepared by diluting the stock to $100 \mathrm{ng} / \mu \mathrm{L}$ for utilizing as DNA template in polymerase chain reaction (PCR).

\section{Luteinizing hormone estimation}

For LH level estimation in bulls $(\mathrm{n}=80)$, five milliliters blood was collected in serum separator tube (SST) immediately after ejaculation because as per [10] sexual stimulation such as site of a cow, teasing and on one occasion the act of ejaculation caused an immediate release of large amount of LH. Blood samples were allowed to clot and centrifuged at $1,000 \times \mathrm{g}$ for 15 minutes, from which serum samples were aliquoted and stored at $-20^{\circ} \mathrm{C}$ to $-80^{\circ} \mathrm{C}$ until analyzed for $\mathrm{LH}$ concentrations.

Serum LH concentrations were determined by CUSABIO Bovine LH ELISA Kit. Calculations were done using the professional software "cure expert 1.3" developed by Hyams. Duplicate readings for each standard and sample were averaged and optical density of blank was subtracted from standard and sample. A standard curve was established by reducing the data using computer software capable of generating four parametric logistic (4-PL) curve fit and LH concentrations was calculated. Sensitivity was less than $1.56 \mathrm{mIU} / \mathrm{mL}$ and intraand inter-assay coefficients of variation were $<15 \%$.

\section{Evaluation of semen quality}

Semen quality traits like semen volume per ejaculate, sperm concentration (million/mL), percent individual motility, percent non-eosinophilic spermatozoa, percent normal spermatozoa, percent membrane integrity in both fresh and postthawed frozen semen were obtained from each ejaculate according to the guidelines of the World Health Organization [11]. The semen samples were collected from each bull in 3 to 6 days intervals using artificial vagina during three different seasons viz., rainy (July to October), winter (November to February) and summer (March to June). Two ejaculates per bull in a season were used for semen quality evaluation and mean value obtained was used for association studies.

Immediately after collection, the ejaculates were stored at $37^{\circ} \mathrm{C}$ in water bath prior to the evaluation for semen quality traits. The ejaculate volume was measured in a sperm collecting vial and counted. Sperm concentration (million/mL) was determined by using a digital photometer with auto dilutor (SMILE software, IMV Technologies, Paris, France). Percent live spermatozoa, percent membrane integrity, percent acrosome integrity and percent normal spermatozoa were determined using standard protocols. The percent live spermatozoa were estimated by Eosin-Nigrosin staining [12], wherein the dead cells take the eosin stain, whereas live cells remain un-stained. Percent membrane integrity of spermatozoa was determined by using HOST. The percentage of hypoosmotic swelling test reacted cells (cells with coiled tail) in hypo osmotic solution (150 mOsmol/L) was determined [13]. Percent acrosomal integrity of the spermatozoa was studied by Giemsa's staining of fixed smears and cells with intact acrosome were counted [14]. After storage in liquid nitrogen for 5 to 7 days, two straws were randomly obtained from each bull, thawed at $37^{\circ} \mathrm{C}$ for $30 \mathrm{~s}$, and immediately evaluated for the percent post thaw sperm motility according to the guidelines 
of the World Health Organization [11]. In brief, the post thaw spermatozoa were viewed on a TV monitor connected to a camera mounted onto a phase contrast microscope (OlympusBX40, Minitub, Tiefenbach, Germany) at $100 \times$ magnification by placing a drop of semen on to a pre-warmed $\left(37^{\circ} \mathrm{C}\right)$ slide and overlaying it with a slip cover.

\section{Primer design and polymerase chain reaction} amplification of $L H \beta$ gene

Three sets of overlapping primers were designed for $L H \beta$ gene based on reference sequence of Bubalus bubalis (NCBI Reference Sequence: NW_005783642.1) by using primer 3 (V.0.4.0) (http://primer3.ut.ee/) online software for amplifying the complete gene and were procured from Sigma-Aldrich Chemicals Pvt. Ltd. Bengaluru, India. The details of the primers, targeted region, annealing temperature, and expected product sizes are summarized in Table 1.

The PCR was carried out on approximately $100 \mathrm{ng}$ of genomic DNA in $25 \mu \mathrm{L}$ per reaction volume. The PCR reaction mixture consisted of $200 \mu \mathrm{M}$ of each dNTPs, $10 \times$ Taq Pol assay buffer, $1 \mathrm{U}$ Taq polymerase enzyme (Genet Bio, Daejeon, Korea) and $20 \mathrm{pM}$ of each primer (Sigma Aldrich, St. Louis, MO, USA). The thermocycler conditions included an initial denaturation at $94^{\circ} \mathrm{C}$ for $2 \mathrm{~min}$, followed by 35 cycles of denaturation at $94^{\circ} \mathrm{C}$ for $30 \mathrm{~s}$ with varying annealing temperatures based on primer set (Table 1), extension at $72^{\circ} \mathrm{C}$ for $1 \mathrm{~min}$, followed by a final extension at $72^{\circ} \mathrm{C}$ for $10 \mathrm{~min}$. The PCR products were electrophoresed at $100 \mathrm{~V}$ in $1.5 \%$ agarose gel in $1 \times$ tris borate EDTA (TBE) (Sigma Aldrich, USA) buffer containing $0.5 \mu \mathrm{g} / \mathrm{mL}$ ethidium bromide (Sigma Aldrich, USA) along with a DNA molecular size marker of $100 \mathrm{bp}$ (Sigma Aldrich, USA). The gels were visualized and documented using Gel documentation system (Gel doc 1000, BioRad, Hercules, CA, USA).

\section{PCR-SSCP analysis}

The genetic variants were determined by single strand conformation polymorphism (SSCP) technique. Amplified PCR products $(10 \mu \mathrm{L})$ were further diluted in $10 \mu \mathrm{L}$ of denaturing solution ( $95 \%$ formamide, $10 \mathrm{mM} \mathrm{NaOH}, 0.05 \%$ xylene cyanol, 0.05\% bromophenol blue, and $20 \mathrm{mM}$ EDTA, Sigma Aldrich,
USA) and denaturation was carried out at $95^{\circ} \mathrm{C}$ for $5 \mathrm{~min}$ followed by rapid chilling on an ice block for $20 \mathrm{~min}$ and loaded on 10\% acrylamide:bisacrylamide (29:1, Sigma Aldrich, USA) in $1 \times$ TBE (Sigma Aldrich, USA) buffer for $15 \mathrm{~h}(200 \mathrm{~V})$ at $4^{\circ} \mathrm{C}$. The gels were silver stained as described by Sambrook and Russell [15]. Band patterns were characterized by the number of bands and mobility shifts, and each pattern was scored manually. To confirm the mobility shift in each pattern, PCR products of each SSCP pattern in duplicates were chosen and custom sequenced using automated ABI DNA Sequencer 3730 XL (Thermo Fisher Scientific, Meridian Road, Rockford, IL, USA) for detecting single nucleotide polymorphisms (SNPs). Sequence data were analyzed using DNA Baser (Heracle BioSoft SRL, Pitesti, Romania) and Clustal W multiple sequence alignment software (developed by Des Higgins) for detecting SNPs [16] by comparing the observed sequence of the $L H \beta$ gene in Murrah bulls with the NCBI Resource Coordinators (2016). Database resources of the National Center for Biotechnology Information. Nucleic Acids Research, 44(Database issue), D7-D19. http://doi.org/10.1093/nar/gkv1290) reference sequence for Bubalus bubalis.

\section{Statistical analysis}

The associations between SSCP pattern set of three exons in $L H \beta$ gene and semen quality traits were analyzed using the general linear model (GLM) and compared by Duncan's multiple range test of SPSS software (Version 16.0, SPSS Inc. Released 2007. SPSS for Windows, Chicago, IL, USA).

The linear model is represented as follows:

$$
\mathrm{Y}_{\mathrm{i} j \mathrm{klm}}=\mu+\mathrm{I}_{\mathrm{i}}+\mathrm{A}_{\mathrm{j}}+\mathrm{S}_{\mathrm{k}}+\mathrm{G}_{\mathrm{l}}+\mathrm{e}_{\mathrm{ijk} k \mathrm{~m}}
$$

Where, $Y_{i j k l m}=$ observed value of $m^{\text {th }}$ bull in $\mathrm{i}^{\text {th }}$ herd, $\mathrm{j}^{\text {th }}$ age group, $\mathrm{k}^{\text {th }}$ season and $\mathrm{l}^{\text {th }}$ genotype for each semen quality trait. $\mu=$ overall mean, $I_{i}=$ fixed effect of $i^{\text {th }}$ herd $(1=$ State Livestock Breeding and Training Centre, $2=$ Nandini Sperm Station and 3 = Centralized Semen Collection Centre of Livestock Breeding and Training Centre), $A_{j}=$ fixed effect of $j^{\text {th }}$ age ( 1 $=2-4$ years, $2=4-6$ years, $3=6-8$ years and $4=\geq 8$ years), $S_{k}$ $=$ fixed effect of $\mathrm{k}^{\text {th }}$ season $(1=$ rainy, $2=$ winter, and $3=$ sum-

Table 1. Primer sequences ( $5^{\prime}$ to $3^{\prime}$ ) used for amplification of $L H \beta$ gene

\begin{tabular}{|c|c|c|c|c|c|}
\hline Gene & Primer & Sequence $\left(5^{\prime}\right.$ to $\left.3^{\prime}\right)$ & Region covered & Annealing Temp., $\mathrm{T}_{\mathrm{a}}\left({ }^{\circ} \mathrm{C}\right)$ & Product size (bp) \\
\hline \multirow[t]{5}{*}{$\mathrm{LH} \beta$} & Exon 1 & F CTTGCCTCTCTCTGACCTTG & & 61 & 466 \\
\hline & & R CACTGGCCTTGTCCCAGGGA & 5'UTR+Exon 1+Partial intron 1 & & \\
\hline & Exon 2 & F CTGAGGTCTTGGGGTGTCTA & & 60 & 505 \\
\hline & & R GCCTGAGTCTGGGATCTGTG & Partial intron 1+Exon 2+Partial intron 2 & & \\
\hline & Exon 3 & $\begin{array}{l}\text { F CATAGAAGACCGGAAGTGGCA } \\
\text { R TTCTCAAACTGCACTCCGAG }\end{array}$ & Partial intron 2+Exon 3+Intron 3 & 61 & 530 \\
\hline
\end{tabular}

$L H \beta$, luteinizing hormone beta. 
mer), $G_{1}=$ fixed effect of $\mathrm{I}^{\text {th }}$ SSCP pattern set of three exons, $\mathrm{e}_{\mathrm{ijk} \mathrm{km}}=$ random error which is normally and independently distributed with mean 0 and variance $\sigma_{\mathrm{e}}^{2}$ ).

The association between $L H \beta$ SSCP pattern set and $\mathrm{LH}$ concentrations was studied using the GLM and compared by Duncan's multiple range test of SPSS software (Version 16.0, SPSS Inc. Released 2007. SPSS for Windows, USA). The linear model is represented as follows:

$$
\mathrm{Y}_{\mathrm{ij}}=\mu+\mathrm{G}_{\mathrm{i}}+\mathrm{e}_{\mathrm{ij}}
$$

Where, $Y_{i j}=$ observation of $j^{\text {th }}$ bull having $i^{\text {th }}$ genotype for hormone concentration. $\mu=$ overall mean, $G_{i}=$ fixed effect of $i^{\text {th }}$ SSCP pattern set, $e_{i j}=$ random error is normally and independently distributed with mean 0 and variance $\sigma_{e}^{2}$.

\section{RESULTS}

\section{Genetic characterization of $L H \beta$ gene}

The polymorphism in $L H \beta$ gene was investigated using three sets of overlapping primers by PCR-SSCP analysis. Exon 1 showed polymorphism within the population. Unique SSCP patterns with different mobility shifts, pattern 1 and pattern
2 were observed (Figure 1). The frequency of pattern 1 and pattern 2 were 0.2018 and 0.7982 , respectively. PCR-SSCP analysis of exon 2 showed polymorphism within the population. Unique SSCP patterns with different mobility shifts, pattern 1, pattern 2, and pattern 3 were observed (Figure 2). The frequency of SSCP variants pattern 1, pattern 2, and pattern 3 were $0.2844,0.5046$, and 0.2110 , respectively and similarly, PCR-SSCP analysis of exon 3 showed two unique SSCP patterns (Figure 3). Pattern 1 and pattern 2 with frequency of 0.4954 and 0.5046 , respectively. SSCP band patterns along with their frequency are shown in Table 2.

PCR products showing unique SSCP patterns were custom sequenced and analyzed. The analysis revealed one silent mutation $\mathrm{g}$ G355869A in the partial intron 1 region (Table 3). Pattern 1 was similar to the Bubalus bubalis reference sequence having $G$ at position 355869 whereas pattern 2 bulls were heterozygous with $\mathrm{A} / \mathrm{G}$ at this site.

In exon 2, two transversions, g C356090A and g G356330C and one transition g C356113T were observed. Out of these, C356090A and g C356113T were present in the coding region while g G356330C was present in the intron 2. At position 356090, pattern 1, pattern 2, and pattern 3 were carrying C, A/C, and C nucleotides, respectively. At position 356113, pat-

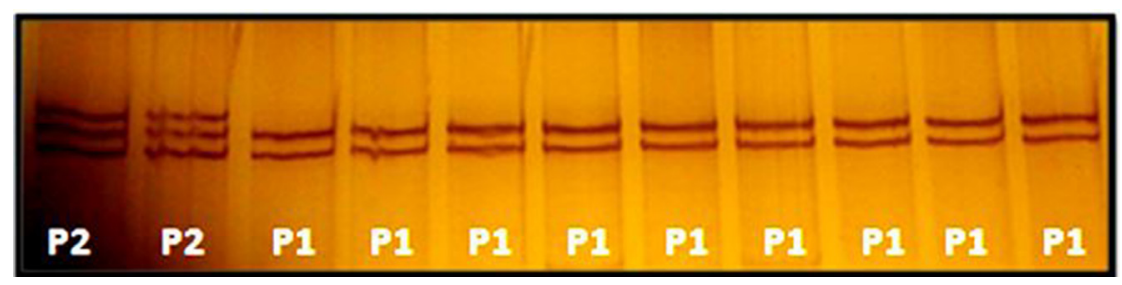

Figure 1. Polymerase chain reaction-single stranded conformational polymorphism pattern of exon 1 of luteinizing hormone beta gene.

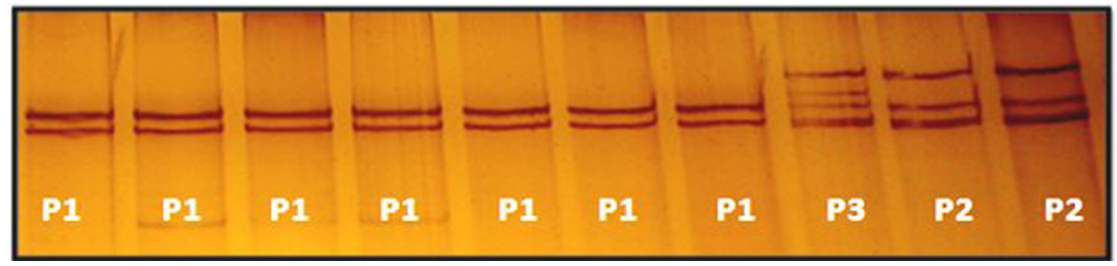

Figure 2. Polymerase chain reaction-single stranded conformational polymorphism pattern of exon 2 of luteinizing hormone beta gene.

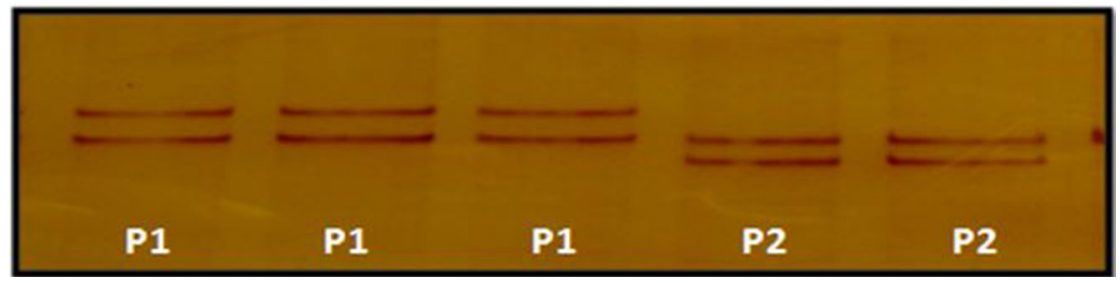

Figure 3. Polymerase chain reaction-single stranded conformational polymorphism pattern of exon 3 of luteinizing hormone beta gene. 
Table 2. Frequency of SSCP variants of $L H \beta$ gene

\begin{tabular}{lccc}
\hline Region & Pattern/genotype & $\begin{array}{c}\text { Number of } \\
\text { observations }\end{array}$ & $\begin{array}{c}\text { Frequency of SSCP } \\
\text { variants }\end{array}$ \\
\hline Exon 1 & pattern 1 & 22 & 0.2018 \\
& pattern 2 & 87 & 0.7982 \\
Exon 2 & pattern 1 & 31 & 0.2844 \\
& pattern 2 & 55 & 0.5046 \\
& pattern 3 & 23 & 0.2110 \\
Exon 3 & pattern 1 & 54 & 0.4954 \\
& pattern 2 & 55 & 0.5046 \\
\hline
\end{tabular}

SSCP, Single stranded conformational polymorphism; $L H \beta$, luteinizing hormone beta.

tern 1, pattern 2, and pattern 3 were carrying $\mathrm{C}, \mathrm{C}$, and T/C nucleotides, respectively. At position 356330, pattern 1, pattern 2 , and pattern 3 were carrying G, C/G, and G nucleotides, respectively. Pattern 1 was similar to the reference Bubalus bubalis sequence whereas pattern 2 was different from pattern 1 . All mutations found in the $L H \beta$ exon 2 were silent mutations (Table 3).

In the present study, exon 3 was found to be polymorphic at two sites leading to transition at position $\mathrm{g}$ A356701G in the coding region and transversion at $\mathrm{g}$ G356606 $\mathrm{T}$ in the third intron of $L H \beta$ gene as compared to Bubalus bubalis reference sequence. Mutation at g A356701G leads to change in amino acid from Histidine to Arginine (Table 3). The bulls showing pattern 1 were homozygous at the two sites with $A$ and $G$ nucleotides respectively and were similar to reference sequence. The bulls with pattern 2 were heterozygous at both sites with $\mathrm{G} / \mathrm{A}$ and $\mathrm{T} / \mathrm{G}$ respectively. Chromatograph analysis of first, second and third fragments of $L H \beta$ gene is shown in Figures 4, 5, 6, respectively. Sequence for $L H \beta$ gene was submitted to Gene Bank with the accession number KY786093. SNP's identified in the $L H \beta$ gene of Murrah bulls were compared with other bovine species having transcript ENSBTAT00000057054.1. None of the SNP's identified in the $L H \beta$ gene of Murrah bulls was similar to other bovines, thereby reflecting their specificity to $L H \beta$ gene of Murrah bulls.

\section{Association of SSCP pattern set with semen quality parameters}

SSCP variants of pattern 2 of exon $1+$ pattern 2 of exon $2+$ pattern 1 of exon 3 had highly significant effect $(\mathrm{p}<0.01)$ on sperm concentration (million $/ \mathrm{mL}$ ), percent mass motility, acrosome integrity and membrane integrity in fresh and frozen semen whereas significant $(\mathrm{p}<0.05)$ effect was observed on percent live spermatozoa. Bulls with pattern 2 of exon $1+$ pattern 2 of exon 2+pattern 1 of exon 3 had the highest sperm concentration $\left(1,334.11 \pm 74.04 \times 10^{6} / \mathrm{mL}\right)$, percent mass motility $(71.85 \pm$ $1.32)$, percent live spermatozoa $(74.85 \pm 2.17)$ fresh semen percent acrosome integrity $(77.20 \pm 1.20)$, fresh semen percent membrane integrity $(72.75 \pm 1.41)$, frozen semen percent acrosome integrity $(70.30 \pm 1.32)$ and frozen semen percent membrane integrity $(66.02 \pm 0.95)$ compared to bulls with pattern 2 of exon $1+$ pattern 1 of exon $2+$ pattern 2 of exon 3 and pattern 2 of exon $1+$ pattern 2 of exon $2+$ pattern 2 of exon 3 (Table 4).

\section{Association of $L H \beta$ genetic variants with $L H$ hormone concentrations}

SSCP variants of pattern 2 of exon $1+$ pattern 2 of exon $2+$ pattern 1 of exon 3 had highly significant $(\mathrm{p}<0.01)$ effect on $\mathrm{LH}$

Table 3. Summary of single nucleotide polymorphism observed in $L H \beta$ gene in Murrah bulls

\begin{tabular}{lccccc}
\hline Region & Locus & Bubalus bubalis & Murrah & Type of variation & Amino acid change \\
\hline Exon 2 & 356090 & $\mathrm{C}$ & $\mathrm{A} / \mathrm{C}$ & Transversion & No change \\
& 356113 & $\mathrm{C}$ & $\mathrm{T} / \mathrm{C}$ & Transition & No change \\
Exon 3 & 356701 & $\mathrm{~A}$ & $\mathrm{G} / \mathrm{A}$ & Transition & Histidine to arginine \\
Intron 1 & 355869 & $\mathrm{G}$ & $\mathrm{A} / \mathrm{G}$ & Transition & - \\
Intron 2 & 356330 & $\mathrm{G}$ & $\mathrm{C} / \mathrm{G}$ & Transversion & - \\
Intron 3 & 356606 & $\mathrm{G}$ & $\mathrm{T} / \mathrm{G}$ & Transversion & - \\
\hline
\end{tabular}

$L H \beta$, luteinizing hormone beta.

Table 4. Effect of combined patterns of three exons of the $L H \beta$ gene on the semen quality parameters (mean \pm SE)

\begin{tabular}{|c|c|c|c|c|c|c|c|c|c|c|c|c|c|}
\hline \multirow{2}{*}{ effects ${ }^{1)}$} & \multirow{2}{*}{$\begin{array}{c}\text { Concentration } \\
\text { (millions of cells } / \mathrm{mL} \text { ) }\end{array}$} & \multirow{2}{*}{$\begin{array}{l}\text { Volume } \\
(\mathrm{mL})\end{array}$} & \multirow{2}{*}{$\begin{array}{c}\text { Mass } \\
\text { motility (\%) }\end{array}$} & \multirow{2}{*}{$\begin{array}{l}\text { Post thaw } \\
\text { motility (\%) }\end{array}$} & \multirow{2}{*}{ ive (\%) } & \multirow{2}{*}{ lormal (\%) } & & Mid & & \multirow{2}{*}{$\begin{array}{c}\text { Fresh } \\
\text { Giemsa (\%) }\end{array}$} & \multirow{2}{*}{$\begin{array}{c}\text { Fresh HOST } \\
(\%)\end{array}$} & \multirow{2}{*}{$\begin{array}{c}\text { Frozen } \\
\text { Giemsa (\%) }\end{array}$} & \multirow{2}{*}{$\begin{array}{c}\text { Frozen HOST } \\
(\%)\end{array}$} \\
\hline & & & & & & & & A & & & & & \\
\hline$E 2+P 1 E 3$ & $4^{b}$ & & $32^{\mathrm{a}}$ & & $.17^{\mathrm{a}}$ & & & & & & 72.75 & & $95^{\mathrm{a}}$ \\
\hline $2 \mathrm{E}$ & & & & & & & & & & & & & \\
\hline $2 \mathrm{E} 1+\mathrm{P} 2$ & $1,309.11 \pm 101.76^{b}$ & $4.66 \pm 0.33$ & $69.05 \pm 1.82^{\mathrm{a}}$ & $44.46 \pm 0.41$ & $69.23 \pm 2.99^{b}$ & $86.77 \pm 1.25$ & $7.11 \pm 0.27$ & 45 & $6.33 \pm 0.87$ & $73.41 \pm 0.97^{\mathrm{ab}}$ & $67.53 \pm 1.70^{b}$ & $66.82 \pm 0.98^{b}$ & $60.71 \pm 1.31^{b}$ \\
\hline -value & $0.002^{*}$ & 0.877 & $0.001^{* *}$ & 0.701 & $0.006^{*}$ & 0.294 & 0.360 & 0.324 & 0.307 & $0.001^{* *}$ & $0.001^{* *}$ & $0.001^{* *}$ & $0.001^{* *}$ \\
\hline
\end{tabular}

$L H \beta$, luteinizing hormone beta; $S E$, standard error.

1) P2E1, pattern 2 of exon 1; P2E2, pattern 2 of exon 2; P1E3, pattern 1 of exon 3; P1E2, pattern 1 of exon 2; P2E3, pattern 2 of exon 3.

${ }^{a b}$ Values bearing different superscripts between rows significantly differ from each other, and $p$ values bearing * and ** differ significantly at $p \leq 0.05$ and $p \leq 0.01$ level.

Pattern sets having frequency less than 10 were removed from analysis. 


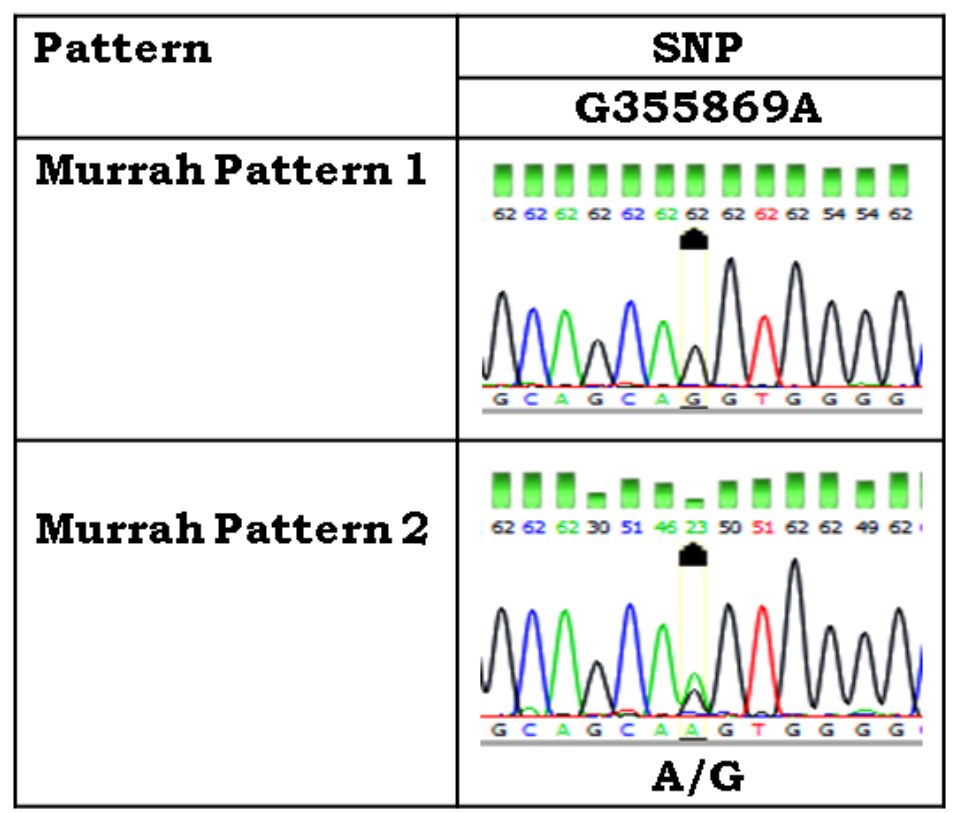

Figure 4. Sanger traces figures of single stranded conformational polymorphism variant sites of exon 1 of luteinizing hormone beta gene.

concentrations. Bulls with pattern 2 of exon $1+$ pattern 2 of exon $2+$ pattern 1 of exon 3 had the highest $\mathrm{LH}$ concentrations (26.98 \pm 2.58$)$ compared to pattern 2 of exon $1+$ pattern 2 of exon $2+$ pattern 2 of exon $3(19.23 \pm 2.94)$ (Table 5).

\section{DISCUSSION}

PCR-SSCP is a simple, sensitive and efficient technique for identifying the genetic variations in candidate genes. The study revealed six SNPs in the $L H \beta$ gene in Murrah bulls. Our findings regarding characterization of $L H \beta$ gene were in agreement with the findings of earlier researchers [13]. They reported seven different SNPs in the $L H \beta$ gene in Indian river buffalo by using PCR-SSCP technique and direct sequencing methods. In all variants, amino acid substitutions were noted. Therefore, $L H \beta$ gene was not highly conserved and non-syn-

\begin{tabular}{|c|c|c|c|}
\hline \multirow[t]{2}{*}{ Pattern } & \multicolumn{3}{|c|}{ SNPs } \\
\hline & C356090A & C356113T & G356330C \\
\hline Murrah Pattern 1 & 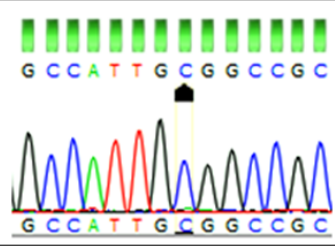 & 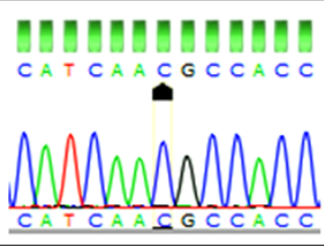 & \\
\hline Murrah Pattern 2 & 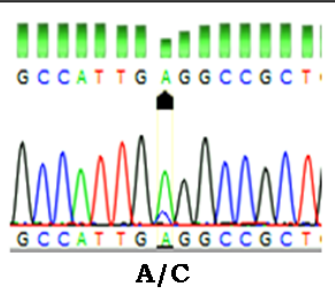 & $\underset{C A T C A A C G C A C C}{C A T C A C G C C A C C}$ & 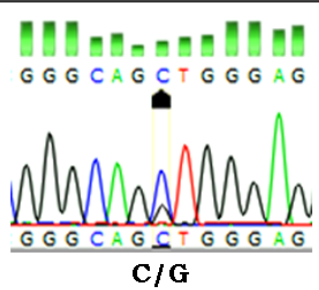 \\
\hline Murrah Pattern 3 & 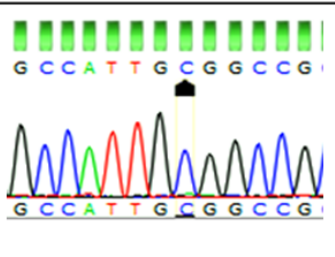 & $\frac{\underbrace{}_{C A T C A}}{\text { T/C }}$ & 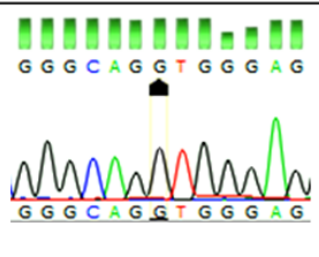 \\
\hline
\end{tabular}

Figure 5. Sanger traces figures of single stranded conformational polymorphism variant sites of exon 2 of luteinizing hormone beta gene. 


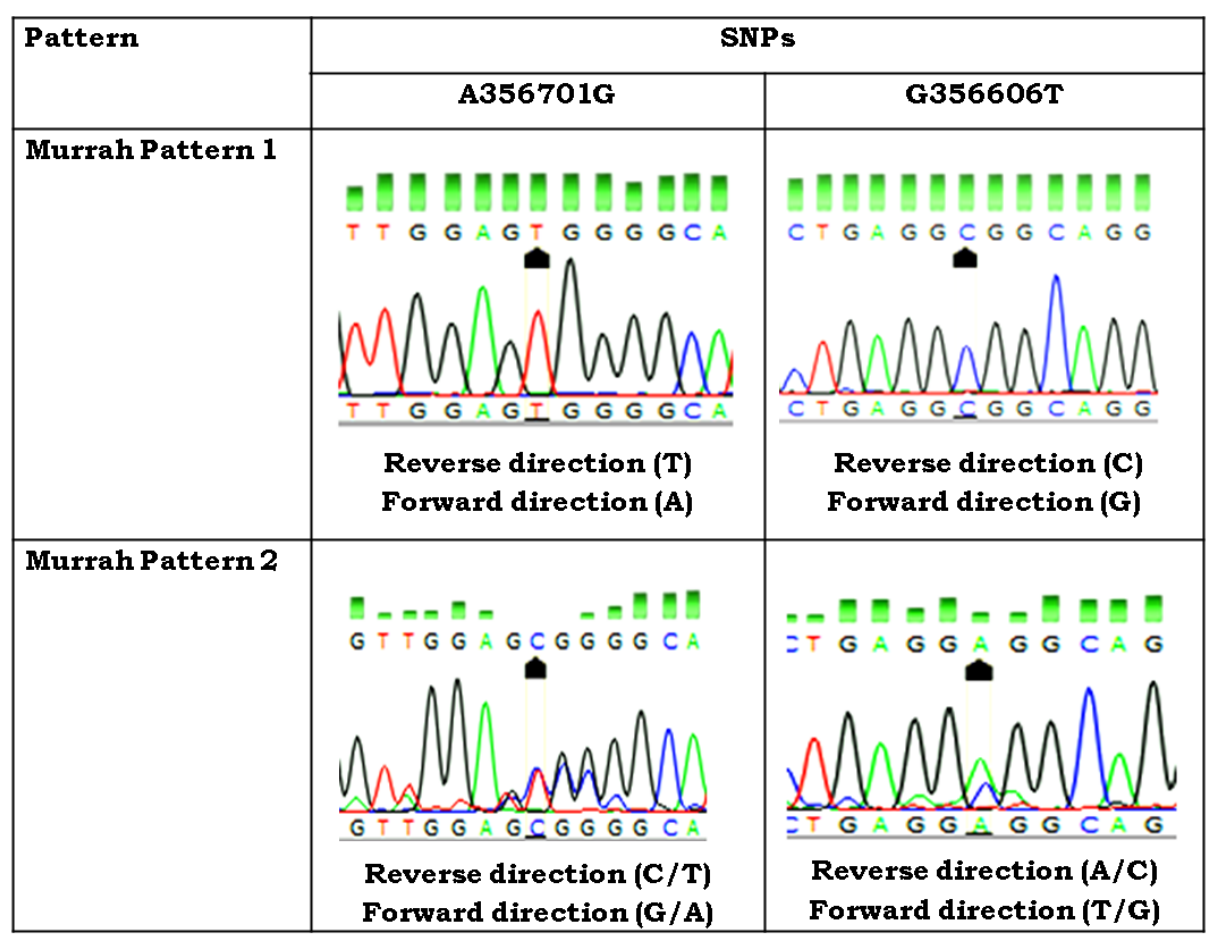

Figure 6. Sanger traces figures of single stranded conformational polymorphism variant sites of exon 3 of luteinizing hormone beta gene.

onymous mutations were observed. In comprehensive view, it appears that the bulls with pattern 2 of exon $1+$ pattern 2 of exon $2+$ pattern 1 of exon 3 could be used as a marker for selecting higher sperm concentration, mass motility, live spermatozoa acrosome integrity and membrane integrity. In the present study, coding as well as non-coding regions of $L H \beta$ gene was highly polymorphic and had strong association with semen quality parameters in Murrah bulls. Our findings are in agreement with those of the previous investigation [17]. They also reported the significant association of $L H \beta$ gene polymorphism with semen concentration in Chinese Buffaloes.

The hormones and their receptors genes are good candidate markers for bull semen traits due to their modulating roles in many male reproductive pathways [2]. Our results indicated that genetic polymorphism in $L H \beta$ gene lead to variation in LH concentrations which could directly affect the quality of

Table 5. Effect of combined patterns of three exons of the $L H \beta$ gene on Luteinizing hormone concentration (mean \pm SE)

\begin{tabular}{lc}
\hline Effects $^{1)}$ & Luteinizing hormone concentration $(\mathrm{mlU} / \mathrm{mL})$ \\
\hline P2E1+P2E2+P1E3 & $26.98 \pm 2.58^{\mathrm{a}}$ \\
$\mathrm{P} 2 \mathrm{E} 1+\mathrm{P} 2 \mathrm{E} 2+\mathrm{P} 2 \mathrm{E} 3$ & $19.23 \pm 2.99^{\mathrm{b}}$ \\
p-value & $0.001^{* *}$ \\
\hline
\end{tabular}

$L H \beta$, luteinizing hormone beta; $S E$, standard error.

1) P2E1, pattern 2 of exon 1; P2E2, pattern 2 of exon 2; P1E3, pattern 1 of exon 3; P2E3, pattern 2 of exon 3.

${ }^{a b}$ Values bearing different superscripts between rows significantly differ from each other, and $p$ values bearing ** differ significantly at $p \leq 0.01$ level.

Pattern sets having frequency less than 10 were removed from analysis. semen. The Murrah bulls with pattern 2 of exon $1+$ pattern 2 of exon 2+pattern 1 of exon 3 could be selected as a marker for higher LH concentrations because these bulls had higher semen concentration, percent mass motility, percent live spermatozoa, percent acrosome integrity and membrane integrity. Published reports are not available to compare the association of SSCP variants of $L H \beta$ gene with LH concentrations in Murrah bulls. Therefore, findings of this study are compared with those reported in cattle. Some researchers [18] suggested that the mutations in the 5' upstream regulation regions would have altered the binding sites of transcription factors affecting the transcription leading to variation in FSH concentrations in cattle. Consequently, it becomes very important to identify mutations and their impact on traits of interest because all mutations might not be favorable and some can interrupt cellular functions thereby decreasing the performance of important economic traits.

\section{CONCLUSION}

Based on the findings from the present investigation, it is concluded that $L H \beta$ gene exhibited high degree of genetic variability in Murrah bulls. The identified SSCP pattern set with pattern 2 of exon $1+$ pattern 2 of exon $2+$ pattern 1 of exon 3 is significantly associated with semen quality parameters and hormone concentrations, which could be used as a genetic marker in Marker Assisted Selection after validating the same SSCP pattern using large number of Murrah bulls from differ- 
ent herds.

\section{CONFLICT OF INTEREST}

We certify that there is no conflict of interest with any financial organization regarding the material discussed in the manuscript.

\section{ACKNOWLEDGMENTS}

The Authors are thankful to the Director, NDRI, Karnal and Head, SRS of NDRI, Bengaluru for providing the necessary facilities, financial assistance and also to the Director of "Karnataka Livestock Development Agency" (KLDA), Government of Karnataka, for providing necessary facilities to work in their organized semen stations.

\section{REFERENCES}

1. Mathevon M, Buhr MM, Dekkers JCM. Environmental, management and genetic factors affecting semen production in Holstein bulls. J Dairy Sci 1998;81:3321-30.

2. Giesecke K, Hamann H, Sieme H, Distl O. INHBA-associated markers as candidates for stallion fertility. Reprod Domest Anim 2010;45:34247.

3. Pierce JG, Parsons TF. Glycoprotein hormones structure and function. Ann Rev Biochem 1981;50:465-95.

4. Gharib SD, Wierman ME, Shupnik MA, Chin WW. Molecular biology of the pituitary gonadotropins. Endocr Rev 1990;11: 177-99.

5. Talmadge K, Booratein WR, Fiddes JC. The human genome contains seven genes for the $\beta$-subunit of chorionic gonadotropin but only one gene for the $\beta$-subunit of luteinizing hormone. DNA 2009;2:281-9.

6. Huhtaniemi I, Jiang M, Nilsson C, Pettersson K. Mutations and polymorphisms in gonadotropin genes. Mol Cell Endocrinol 1999;25:89-94.

7. Elkins DA, Yokomizo A, Thibodeau SN. Luteinizing hormone beta polymorphism and risk of familial and sporadic prostate cancer. Prostate 2003;56:30-6.

8. Basavarajappa MS, De S, Thakur M, et al. Characterization of the luteinizing hormone beta (LH $\beta)$ subunit gene in the Indian River buffalo (Bubalus bubalis). Gen Comp Endocrinol 2008;155:63-9.

9. Miller SA, Dykes D, Polesky HF. A sample salting out procedure for extracting DNA from human nucleated cells. Nucleic Acids Res 1988;16:1215.

10. Katongole CB, Naftolin F, Short RV. Relationship between blood levels of luteinizing hormone and testosterone in bulls, and the effects of sexual stimulation. J Endocrinol 1971;50:45766.

11. World Health Organization. WHO laboratory manual for the examination of human semen and semen-cervical mucus interaction. 4th ed. New York, USA: Cambridge University Press; 1999.

12. Blom EA. Rapid staining method using eosin-nigrosin to distinguish between live and dead spermatozoa. Nord Vet Med 1950;18:1390.

13. Muhammad Z, Akbar LL, Ahmad E, Muhammad G. Hypo osmotic swelling test as screening for evaluation of semen of bull. J Entomol Zool Stud 2013;1:124-8.

14. Correa JR, Zavos PM. The hypo-osmotic swelling test; its employment as an assay to evaluate the functional integrity of the frozen-thawed bovine sperm membrane. Theriogenology 1994;42:351-60.

15.Sambrook J, Russell DW. Molecular cloning. A laboratory manual. 3rd ed. Cold Spring Harbor, NY, USA: Cold Spring Laboratory Press; 2001.

16. Hall TA. Bio-Edit: a user-friendly biological sequence alignment editor analysis program for Windows 95/98/ NT. Nucleic Acids Symp Ser 1999;41:95-8.

17. Cheng Y, Gu J, Xue H, et al. Identification of four SNPs in LHB gene and their associations with sperm qualities of Chinese buffaloes. Anim Biotechnol 2017;28:168-73.

18. Dai L, Zhihui Z, Zhao R, et al. Effects of novel single nucleotide polymorphisms of the FSH beta-sub unit gene on semen quality and fertility in bulls. Anim Reprod Sci 2009;114:14-22. 